\title{
Students' Writing Quality: Its Coherence and Cohesion
}

\author{
Alief Noor Farida \\ English Department \\ Universitas Negeri Semarang, Indonesia \\ Email: aliefnoorfarida@mail.unnes.ac.id \\ Mohamad Ikhwan Rosyidi \\ English Department \\ Universitas Negeri Semarang, Indonesia \\ Email: mirosyidi@mail.unnes.ac.id
}

\begin{abstract}
Students' writing quality has become the focus of education research nowadays. A good quality writing should fulfil the requirements of coherence and cohesion. Coherence shows how the sentences in the text are arranged which usually follow certain structure, and cohesion shows how they are connected to each other. This study aims to investigate the students' writing quality in both aspects. Using systemic functional linguistics approach, 10 students' writing on recount text is analysed. The result of the study reveals how good the students on the fourth semester can write the text and what devices they use to establish the quality. The students can follow the generic structure of recount texts well. However, only $50 \%$ has reorientation. In addition, they employ different thematic progressions,
\end{abstract}

Keywords: writing, coherence, cohesion

\section{INTRODUCTION}

Writing needs a lot of efforts. It is not as simply as putting the words together as the aligning words should be able to express the ideas that the writer wants to convey (Peha, 2002). The writer will choose the right dictions to convey what he means. In addition, the ideas should be arranged on specific structure to reach its goal. Different goal or purpose of a text will demand different structure and lexicogrammatical features (Brown, 2001). Therefore, when we want to write in English, the generic structure of English text types should be followed to be understood easily by the readers.

Generic structure of texts is different, depending on the purposes of the text, called genre. Genre has a certain recurring pattern which is highly related to its culture (Hammond \& Derewianka, 2001). There are six different groups of English text types, namely narrative, recount, information reports, instruction, explanation, and expository (Derewianka, 1990). In Indonesia, those text types are introduced to students in different school levels, in Junior high school and Senior High School. According to the curriculum, the students learn descriptive, recount, and report in Junior High School, and they learn more texts, like procedure, narrative, expository, and explanation in Senior High School. The curriculum mentions that the students will be able to not only read learned texts but also create the texts (Kemendikbud, 2016).

The generic structure of a text helps students create a coherent text. Coherence, one of indicators of a good text, shows how the sentences are arranged. This follows the requirement of a good paragraph; a paragraph must have a topic sentence, supporting details, and closing sentence (Greco, Sherman, \& Brewer, 2006). The sentences are written in certain ordering: spatial, logical, and chronological ordering (Boardman \& Frydenberg, 2008). Students in Indonesia, who have learned English since Junior High School, should be able to arrange sentences in accordance to the generic structure of certain genres. Students have no problems in following the prescribed generic 
structure of different texts (Nurohmah, 2013; Nurhidayat, 2011; Noviyanti, 2015; Pramono, 2018).

In addition to generic structure and ordering, thematic progression can also help to assess the text's coherence. There are three thematic progression patterns: reiteration, zigzag, and multiple theme patterns (Eggins, 2004). Reiteration patterns appear on a text in which topical theme has a relation to the next clause. Zigzag patterns appear when the theme is derived from the rheme of the previous clause. Multiple theme patterns appear when the theme has one or more elements which are then distributed to other parts of the following clauses. Noviyanti (2015) shows that the types of thematic progression used by the students show the students' level of achievement. Rahman (2013) shows that low-level students use reiteration theme, and mid-level and highlevel students use zigzag and multiple theme patterns. However, Humphrey, Droga, and Feez (2012) proposed three thematic progression patterns using different terms: linear, chronological, and zigzag pattern. Linear patterns show repletion of theme, chronological patterns use marked theme to set the time of the event, and zigzag patterns use rheme of the clause to be the theme in the next clause. These patterns are used in this study.

Another indicator showing a text's quality is its cohesion. Cohesion shows how the sentences in the text connect to each other (Taboada, 2004). Cohesion of a text can be developed by using cohesive device (Gerot \& Wignel, 1994; Eggins, 2004) to connect the words between clauses in the text (Meyer, 2009). Cohesive devices include grammatical and lexical cohesion. Grammatical cohesion devices are references, conjunction, ellipses, and substitutions. The first grammatical cohesion device, references, is words that are used to appoint other words. There are three types of references: pronominal reference, demonstrative, and comparative. The next one is conjunction. Conjunctions are words that are used to connect clauses. They surely have meaning and create a better text. There are four conjunctions that create different relations: additive (adding similar information or element), adversative (adding dissimilar information), causal (adding reason), and temporal (giving order in the sentence). The next ones are ellipses and substitutions. Ellipses omit some words existed in the previous clause, and substitutions change words with other words. Lexical cohesion create cohesion by using different words, including repetition, synonym, superordinate, general nouns, and collocations. Repetition means that we use the same words repeatedly. Synonym and superordinate mean that we use words with similar or expanded meaning. General nouns mean that we use more general word than the specific words that have been used in the sentences. Collocations mean that we use words that we use the commonly occurring words (Halliday and Hasan, 1976). By using the cohesive devices, it is expected that the sentences in the text will relate to each other. Therefore, coherence and cohesion should exist together in a text to produce a good text. At the same time, coherence and cohesion also show the students' level, whether they are on high or low level. Witte and Faigley (1981) mention that high level students can use synonyms and collocations, while low level students use repetitions more.

When students have reached the university level, it is assumed that they have mastered different texts that they have learned at junior and high schools. Many studies have been done to examine university students' writing quality (Dewi, 2016; Saragih and Septiani, 2017; Ismail and Linda, 2018). However, most of them focus on exposition texts that are high-level text and suitable for university students who should be able to deliver their opinion and show their cognitive ability (Schleppegrell, 2004). Students in English Department of Universitas Negeri Semarang are prepared to be English teachers. They should be able to create any kind of texts that will be taught at schools. 
Therefore, we need to make sure that they can create texts, even the simple one, like recount text. This study aims to examine the students' writing quality in writing recount text, seen from the coherence and the cohesion of the texts.

\section{METHODOLOGY}

This research employs qualitative case study. This study is specific to text analysis which uses Systemic Functional Linguistics approach. Students' final drafts which have passed some writing process on a writing class are the object of this study. However, 10 student writings were randomly taken to be the object of the study. Recount text was chosen as it has been learned since Junior High school. The texts were then analyzed to examine the students' writing quality. The analysis was conducted in the following steps. First, the generic structure of the texts was analyzed using scoring rubric, including orientation, events, and reorientation. Next, the texts' thematic progression was then analyzed to identify the text's coherence. The thematic progression was categorized into linear, chronological, and zigzag pattern (Humphrey, Droga, and Feez, 2012). To examine the cohesion of the texts, cohesive devices used in the texts are analyzed to see what kind of cohesive device is mostly employed by the students to create the text.

\section{RESULTS AND DISCUSSION}

This paper aims to examine the quality of students' writing quality, especially in terms of its coherence and cohesion. The data were 10 recount text written by students in paragraph-based writing. In this course the students learned how to write a good paragraph, including narrative paragraph in the form of recount text. The data were gathered by using instruments (writing rubric) to check whether the texts written by the students have followed the generic structure of recount text and chronological or not to examine the coherence of the texts.
Another analysis on the thematic progression employed by the texts was also done. In addition, the cohesive devices used in the texts were also examined.

\section{The generic structure of the analyzed recount texts}

Recount text is a type of texts that has been taught to Indonesian students since Junior High school level. In English Department of Universitas Negeri Semarang, the students learn to write recount in a writing course. Recount is the simplest narrating text (Knapp and Watkins, 2005). It retells events to inform or entertain the readers. Each text has its own structure to achieve its goal. Recount text has its specific generic structure: Orientation, events, and reorientation (optional).

\section{Orientation}

Of 10 recount texts, it is identified that $90 \%$ texts have followed the generic structure of recount text. The students start their writing by setting the topic. This occurs as the topic sentence of the text (Greco, Sherman, and Brewer, 2006). The topic sentence includes the subject of the event, when or where it happened. In addition, the writer's opinion or feeling will create an effective topic sentence (Oshima and Hogue, 1998). The students' feeling on the event will help them focus on what they are going to retell. However, one text (9) did not write the writer's feeling, so it does not help the readers to guess what happens in the text.

(1) Two years ago, it was a cloudy Sunday evening.

(2) I was involved in a horrible motorcycle accident.

(3) May $20^{\text {th }}, 2014$, was an unforgettable day for me.

(4) Last Friday, I saw an anbocious accident.

(5) The inhuman fire had swallowed a house yesterday.

(6) Sunday, 28 October 2018, a car was involved in a terrible crash in Kebumen which killed two people. 
(7) A terrible road accident took place at Sampangan Highway yesterday.

(8) A traffic accident that happened on the Pantura Street in Rembang City was awful.

(9) One day my father sent me to the shop to buy cool drink.
(10) I lost my beloved cat 5 years ago.

The topic sentence becomes a part of orientation. The following table shows the result of the students' writing quality on orientation.

Table 1 The students' orientation quality

\begin{tabular}{ccc}
\hline The quality & Score & Texts number \\
\hline High & $10-9$ & $1,2,6$ \\
\hline Middle & $8-5$ & $3,4,5,7,8,9,10$ \\
\hline low & $4-0$ & none \\
\hline
\end{tabular}

The following is the example of orientation of the texts that belong to the quality.

Table 2. The Example of Orientation written by students

\begin{tabular}{|c|c|c|}
\hline Quality & Example of orientation & Criteria \\
\hline High & $\begin{array}{l}\text { Two years ago, it was a cloudy } \\
\text { Sunday evening. People were just } \\
\text { staying at home until there was a } \\
\text { loud sound was heard, the sound } \\
\text { was so loud that people started to } \\
\text { come out of their houses, including } \\
\text { me. I was shocked, so were people. }\end{array}$ & $\begin{array}{l}\text { - Show the complete parts of orientation } \\
\text { that are; the people involved, the time, } \\
\text { the places and the situation which make } \\
\text { the readers understand and interest to } \\
\text { read the story } \\
\text { - Well focused idea based on the topic of } \\
\text { an activity }\end{array}$ \\
\hline Middle & $\begin{array}{l}\text { May } 20^{\text {th }}, 2014, \text { was an unforgettable } \\
\text { day for me. }\end{array}$ & $\begin{array}{l}\text { - Does not show one part of the } \\
\text { orientation, e.g. there is no place, } \\
\text { therefore the reader has not received the } \\
\text { complete information from the story } \\
\text { - The writer focuses idea based on the } \\
\text { topic of an activity }\end{array}$ \\
\hline $\begin{array}{l}\text { Events } \\
\text { In the } \\
\text { body of th } \\
\text { students }\end{array}$ & $\begin{array}{l}\text { next part, the students wrote the } \\
\text { e text by telling the events. The } \\
\text { iccessfully wrote the events in }\end{array}$ & $\begin{array}{l}\text { should use chronological ordering (Boardman } \\
\text { \& Frydenberg, 2008) where the sentences are } \\
\text { arranged based on the time of the occurrence } \\
\text { of the event. The following table shows the } \\
\text { quality of students' writing on the event part. }\end{array}$ \\
\hline
\end{tabular}
chronological order. It follows the rule that narrative paragraph, in this case recount text,

Table 3 The students' event quality

\begin{tabular}{ccc}
\hline Quality & Score & Texts number \\
\hline High & $10-9$ & $1,6,10$ \\
\hline Middle & $8-5$ & $2,3,4,5,7,8,9$ \\
\hline low & $4-0$ & none
\end{tabular}

The following table shows the example of the students' writing on the event.

Table 4 The Example of Event written by students 


\begin{tabular}{cll}
\hline Quality & \multicolumn{1}{c}{ Example of orientation } & Criteria \\
\hline High & $\begin{array}{l}\text { Afterwards, I followed my father to go to the source of the } \\
\text { sound, and it was on the crossroad near my house. } \\
\text { Apparently, there were a truck and a motorcycle that had a } \\
\text { big crush. The man who drove the truck was fine and able to } \\
\text { get out of the truck. Meanwhile, the man and the woman } \\
\text { who ride a motorcycle were flung away and were in the } \\
\text { helplessness. After that, there was an ambulance that rushed } \\
\text { the victims to the hospital, and there was police as well to } \\
\text { check the place and witnesses. }\end{array}$ & $\begin{array}{l}\text { States more } \\
\text { than two } \\
\text { events in a }\end{array}$ \\
$\begin{array}{l}\text { I wanted to go to my basketball practice by riding my } \\
\text { motorcycle. I passed the road that was passed by a lot of } \\
\text { trucks. On the way I picked up my friend, I crossed the road } \\
\text { and suddenly the other motorcycle with high speed hit me. } \\
\text { The front side of my motorcycle was destroyed and I broke } \\
\text { my right hand. }\end{array}$ & $\begin{array}{l}\text { story flow in } \\
\text { conerence. }\end{array}$ \\
\hline
\end{tabular}

\section{Reorientation}

In the last part of the students' recount writing, only 5 texts have reorientation part. Reorientation signals the end of the text although it is optional. It usually summarizes the story and shows the author or the actor's comment. The following table shows that the students still have difficulty in making reorientation of a recount text.

Table 5 The students' reorientation quality

\begin{tabular}{ccc}
\hline Quality & Score & Texts number \\
\hline High & $10-9$ & $2,3,4,10$ \\
\hline Middle & $8-5$ & 5 \\
\hline low & $4-0$ & $1,6,7,8,9$ \\
\hline
\end{tabular}

The following table shows the example of the students' writing on the reorientation part

Table 6 The Example of Reorientation written by students

\begin{tabular}{|c|c|c|}
\hline Quality & Example of orientation & Criteria \\
\hline High & $\begin{array}{l}\text { After the accident } 5 \text { years ago, I } \\
\text { got a self-trauma. When I } \\
\text { passed the road with a lot of } \\
\text { trucks and I'm alone, I always } \\
\text { feel afraid and think what if the } \\
\text { accident happens again to me. }\end{array}$ & $\begin{array}{l}\text { - Show the complete parts of reorientation that } \\
\text { are; signals the end, summarizes the story and } \\
\text { leaves his/her comment. Therefore, readers get } \\
\text { the idea of story } \\
\text { - The idea of personal opinions about the topic } \\
\text { or event is clear }\end{array}$ \\
\hline Middle & $\begin{array}{l}\text { The damage was pretty bad but } \\
\text { fortunately Mrs. Susan and her } \\
\text { family were steady with this } \\
\text { accident. }\end{array}$ & $\begin{array}{l}\text { - Does not show one part of reorientation, but } \\
\text { the reader still get the idea of story } \\
\text { - The idea of personal opinions about the topic } \\
\text { or event is unclear }\end{array}$ \\
\hline low & The students do not write the & - End the story with short comment or without \\
\hline
\end{tabular}




\begin{tabular}{|c|c|c|}
\hline Quality & Example of orientation & Criteria \\
\hline & orientation. & $\begin{array}{l}\text { any comments, signals or summary, so the } \\
\text { reader do not realize that story finish } \\
\text { - The idea of personal opinions about the topic } \\
\text { or event is unclear }\end{array}$ \\
\hline
\end{tabular}

The finding indicates that the students do not have problem in arranging the sentences to create a recount text. It confirms the findings of the previous studies that Indonesian students have enough knowledge on generic structure of recount texts (Noviyanti, 2015). The students can add information needed on orientation, and events. However, some of them need to learn more on how to write the reorientation part.

\section{The thematic progression of the analyzed recount texts}

The next analysis done to the recount texts written by the students is thematic progression analysis to examine the text's coherence. There are three thematic progressions used in this analysis: linear, marked theme, and zigzag pattern (Humphrey, Droga, and Feez, 2012). The result shows not all the thematic progressions patterns are employed in the 10 texts.

Table 7 The Thematic Progression Patterns in Students' Recount texts

\begin{tabular}{|l|c|c|c|c|c|c|c|c|c|c|c|}
\hline $\begin{array}{c}\text { The Thematic } \\
\begin{array}{c}\text { Progression } \\
\text { Patterns }\end{array}\end{array}$ & \multicolumn{9}{|c|}{ Used in Texts } & Total \\
& $\mathbf{1}$ & $\mathbf{2}$ & $\mathbf{3}$ & $\mathbf{4}$ & $\mathbf{5}$ & $\mathbf{6}$ & $\mathbf{7}$ & $\mathbf{8}$ & $\mathbf{9}$ & $\mathbf{1 0}$ & \\
\hline Linear & 2 & 2 & 3 & 2 & 2 & 2 & 0 & 10 & 9 & 8 & 40 \\
\hline Chronological & 5 & 3 & 3 & 1 & 2 & 2 & 2 & 0 & 2 & 4 & $\mathbf{2 4}$ \\
\hline Zig-zag & 4 & 5 & 5 & 2 & 2 & 2 & 2 & 2 & 5 & 6 & 35 \\
\hline
\end{tabular}

Different thematic progression patterns are used by the students. Linear pattern is mostly used by the students in writing the text although not all texts show this pattern. They use topical theme in creating the theme of the sentences by repeating the same elements to begin the sentence. This pattern helps the readers to find the new information easily. Zigzag pattern is also frequently used, and all texts employ this pattern. It is an indicator that students can give more new information in logical relation (Eggins, 2004). The least pattern used in this text is chronological pattern. It is out of expectation that the students do not use many marked theme that is usually used in chronological paragraph (Humphrey, Droga, and Feez, 2012), even there is a text (text 8) that use no chronological pattern.

The use of thematic progression patterns in the students' texts indicates that the students still have problems in producing sentences that are connected to each other, which are then developed the coherence of the text. The result of the analysis also shows that the sentences are not connected well because there are some missing messages that should have existed in the text. This disturbs the reader's understanding. Therefore, $70 \%$ of recount texts written by the students are still in low-level because only high achievers use combination of various thematic progression (Noviyanti, 2015). It also confirms Rahman's finding (2013) that only students with good ability in writing can employ different thematic progression patterns.

\section{The Cohesive Device used in the texts}

Cohesive device is another indicator that can be used to assess the students' writing quality. In this study, the recount texts were analyzed on the grammatical and lexical cohesion. Grammatical cohesion shows how 
the students use grammar to maintain cohesion in the text, including reference, conjunction, ellipses, and substitutions, while lexical cohesion shows how different words are used to make connections, including repetition, synonym, superordinate, general nouns, and collocations. The following table summarizes the cohesive devices employed by the texts.

Table 8 The Cohesive Device in Students' Recount texts

\begin{tabular}{|c|c|c|c|c|c|c|c|c|c|c|}
\hline \multirow[t]{2}{*}{ Cohesive Device } & \multicolumn{10}{|c|}{ Used in Texts } \\
\hline & 1 & 2 & 3 & 4 & 5 & 6 & 7 & 8 & 9 & 10 \\
\hline \multicolumn{11}{|c|}{ Grammatical cohesion } \\
\hline References & 4 & 15 & 11 & 6 & 11 & 5 & 4 & 9 & 12 & 13 \\
\hline Conjunctions & 4 & 4 & 3 & 2 & 8 & 4 & 0 & 3 & 5 & 5 \\
\hline Ellipses & 0 & 0 & 0 & 0 & 0 & 0 & 0 & 0 & 0 & 0 \\
\hline Substitutions & 1 & 0 & 0 & 1 & 0 & 0 & 0 & 0 & 0 & 0 \\
\hline \multicolumn{11}{|l|}{ Lexical Cohesion } \\
\hline Repetitions & 4 & 3 & 3 & 5 & 4 & 2 & 2 & 6 & 1 & 1 \\
\hline Synonym & 0 & 0 & 0 & 0 & 0 & 1 & 0 & 2 & 0 & 0 \\
\hline Superordinate & 0 & 0 & 0 & 0 & 0 & 0 & 0 & 0 & 2 & 2 \\
\hline General nouns & 0 & 0 & 0 & 0 & 0 & 0 & 0 & 0 & 0 & 0 \\
\hline Collocation & 4 & 2 & 3 & 2 & 4 & 4 & 2 & 3 & 1 & 4 \\
\hline
\end{tabular}

The study shows that not all cohesive devices are used by the students. Both grammatical and lexical cohesions are utilized. References are mostly used; it is used to repeat the previous nouns in different form (pronoun). The next one is conjunction; it is used to give connections between sentences. As it is a recount text, most conjunctions used are temporal, causal, addition, and adversative conjunctions. Ellipses are not used at all, and substitutions are used the least. For lexical cohesion, repetitions and collocations are highly used. Synonyms and superordinate are less used, while general nouns are not used at all. This finding shows that the students' recount texts are still in low level as Witte and Faigley (1981) confirms that synonyms and collocations are usually used by high achievers, and repetitions are used by low level students.

\section{CONCLUSION}

This study aims to see the students' writing quality, especially in writing recount text. The finding shows that the quality of the students' recount writing is low. In terms of generic structure, the students follow the generic structure of recount text; all the texts have orientation and events, but some of them have no reorientation. It may be caused by the students' inability to add comment or make summary to end the text or by their understanding that orientation is optional, so they leave this part. In terms of coherence seen from thematic progression patterns, the students are considered to be in low level as most of them cannot employ different thematic patterns. Seen from the cohesion, the students' writing is also assessed to be low as they use more repetitions than other lexical cohesive device. Based on this finding of this study, it is suggested that the students are 
taught using different aspects in improving the coherence and cohesion of texts so that the quality of the text written by students is improving.

\section{REFERENCES}

Boardman, C. A., \& Frydenberg, J. (2008). Writing to Communicate: Paragraphs and Essays (3rd ed.). London, UK: Longman.

Brown, H.D. (2001). Teaching by Principles, an Interactive Approach to Language Pedagogy (2nd Ed.). New York: Pearson Education.

Derewianka, B. (1990). Exploring How Texts Work. Newtown: Primary English Teaching Association.

Dewi, R. Winda Herdisa. (2016). A Systemic functional linguistics (SFL) analysis of exposition texts as teaching materials written by pre-service teachers. Journal of English and Education, 4(1), 73-91. Retrieved from http://repository.upi.edu/27011/

Eggins, S. (2004). An Introduction to Systemic Functional Linguistics. NY: Continuum.

Emilia, E., Habibi, N., \& Bangga, L. A. (2018). An analysis of cohesion of exposition texts: An Indonesian context. Indonesian Journal of Applied Linguistics, 7 (3), 515-523.

Faradhibah, R.N., \& Nur, N.A. (2017). Analyzing students' difficulties in maintaining their coherence and cohesion in writing process. Eternal, 3(2). Retrieved from http://journal.uinalauddin.ac.id/index.php/Eternal/article/download/4250/4443

Gerot, L., \& Wignell, P. (1994). Making Sense of Functional Grammar: An Introductory Workbook. Australia: Gerd Stabler.

Greco, H., Sherman, M., \& Brewer, M. (2006). Grammar on the Go! Victoria: Open Book BC.

Halliday, M. A. K., \& Hasan, R. (1976). Cohesion in English. London: Longman.

Hammond, J., \& Derewianka, B. (2001). Genre. In R. Carter \& D. Nunan (Eds). The Cambridge Guide to Teaching English to Speakers of Other Languages. Cambridge: Cambridge University Press.

Humphrey, S., Droga, L., \& Feez, S. (2012). Grammar and Meaning. NSW: Primary English Teaching Association Australia.

Ismail, N. M., \& Linda, L. (2018). Cohesion in foreign language writing. Eternal, 4(2). Retrieved from http://journal.uin-alauddin.ac.id/index.php/Eternal/article/view/4952

Kemendikbud. (2016). Silabus mata pelajaran sekolah menengah atas/madrasah aliyah/sekolah menengah kejuruan/madrasah aliyah kejuruan (SMA/MA/SMK/MAK). Jakarta: Kemdikbud..

Knapp, P., \& Watkins, M. (2005). Genre Text, Grammar: Technologies for Teaching and Assessing Writing. Australia: University of New South Wales Press Ltd.

Meyer, C. F. (2009). Introducing English Linguistics. New York: Cambridge University Press.

Nurohmah, I. (2013). An analysis of students' recount text by using systemic functional grammar. Passage, 1(2), 89-98. Retrieved from https://media.neliti.com/media/publications/190900-EN-an-analysis-of-students-recounttext-by.pdf 
Nurhidayat, T. (2011). Students' Ability in Writing Recount Based On Generic Structure, Language Features and Social Function. Unpublished Final Project.

Noviyanti. (2015). Thematic Progression in Students' Recount Texts. Journal of English and Education, 3(2), 65-76.

Oshima \& Hogue. (1998). Writing Academic English. London: Longman.

Peha, S. (2002). Looking for quality in student writing. Retrieved from https://www.ttms.org/writing_quality/writing_quality.htm

Pramono, S.A. (2018). A systemic functional linguistics-based analysis of students' problems in writing exposition text. Advances in Social Science, Education and Humanities Research, 254 Eleventh Conference on Applied Linguistics (CONAPLIN 2018). Retrieved from https://www.atlantis-press.com/proceedings/conaplin-18/125911444

Rakhman, A. N. (2013). An analysis of thematic progression in high school students' exposition texts. Passage, 1(1), 65-74. Retrieved from https://media.neliti.com/media/publications/190820-EN-an-analysis-of-thematicprogression-in-h.pdf

Saragih, E.E., \& Septiani, S.N.( 2017). An analysis of the cohesion and coherence of students' descriptive writing. English Journal, 20(1), 34-45. Retrieved from http://ejournal.uikabogor.ac.id/index.php/ENGLISH/article/download/1514/1092

Schleppegrell, M.J. (2004). The language of Schooling: A Functional Linguistics Perspective. Mahwah, NJ: Lawrence Erlbaum.

Taboada, M. T. (2004). Building coherence and cohesion: Task-oriented dialogue in English and Spanish. Amsterdam: John Benjamins Publishing Company.

Witte, S., \& Faigley, L. (1981). Coherence, cohesion, and writing quality. College composition and communication, 32(2), 189-204. Retrieved from http://links.jstor.org/sici?sici=0010096X\%28198105\%2932\%3A2\%3C189\%3ACCAWQ\%3E2.0.CO\%3B2-E 